\title{
A Study of the System Magnesium Oxide-Magnesium Chloride-Water and the Heat of Formation of Magnesium Oxychloride
}

\author{
Edwin S. Newman
}

\begin{abstract}
The precipitation of magnesium oxychlorides is discussed, and the results of solubility measurements are given. The heats of solution in $\mathrm{HCl}, 26 \cdot 61 \mathrm{H}_{2} \mathrm{O}\left(2.00 \mathrm{~N} \mathrm{HCl}\right.$ at $\left.25^{\circ} \mathrm{C}\right)$ of four compounds in the system $\mathrm{MgO}-\mathrm{MgCl}_{2}-\mathrm{H}_{2} \mathrm{O}$ were determined. From those data and other data taken from the literature, the heats of formation of the compounds at $25^{\circ} \mathrm{C}$ were calculated. The results are applied to the calculation of the heat of reaction of hardening of magnesium oxychloride cement.
\end{abstract}

\section{Introduction}

Magnesium oxychloride cement is widely used as a conductive flooring material in hospital operating rooms and other locations where an explosion hazard exists. It is also used widely as a general purpose floor in public buildings, stores, street cars, and elsewhere. Basic information concerning the stability of the components of magnesium oxychloride cement is needed to answer questions that arise from time to time in connection with its service life. The heats of formation of the compounds formed constitute part of the necessary fundamental information and are presented in this paper.

The compounds occurring in the system $\mathrm{MgO}$ $\mathrm{MgCl}_{2}-\mathrm{H}_{2} \mathrm{O}$ have been the subject of many investigations since the discovery in 1867 of the cementitious properties of mixtures of magnesium oxide with magnesium chloride solutions. Robinson and Waggaman [1] ${ }^{1}$, Lukens [2], Chassevent [3], Bury and Davies [4], Feitknecht [5], Feitknecht and Held [6], and others have identified the three solid phases occurring at room temperature as $\mathrm{Mg}(\mathrm{OH})_{2}$, $5 \mathrm{Mg}(\mathrm{OH})_{2} \cdot \mathrm{MgCl}_{2} \cdot n \mathrm{H}_{2} \mathrm{O}$, and $3 \mathrm{Mg}(\mathrm{OH})_{2} \cdot \mathrm{MgCl}_{2} \cdot n \mathrm{H}_{2} \mathrm{O}$. Most of the investigations have been concerned with the identification of the magnesium oxychloride compounds or with the study of the setting process of magnesium oxychloride cement. Only Andre [7] has given heat-of-solution data from which heats of formation have been calculated [8].

In the light of the more recent work cited above, Andre's data appears in doubt because of the absence of identification of his material with the presently recognized compounds. This paper gives the results of new measurements of the heats of solution of the two oxychlorides and the heats of formation calculated therefrom.

\section{Materials, Apparatus, and Procedure}

\subsection{Preparation of Compounds}

The compounds were prepared by precipitation at $25^{\circ} \mathrm{C}$ from metastable solutions of $\mathrm{MgO}$ in $\mathrm{MgCl}_{2}$ solutions of various concentrations. Aqueous $\mathrm{MgCl}_{2}$

\footnotetext{
Figures in brackets indicate the literature references at the end of this paper.
}

solutions were prepared from $\mathrm{MgCl}_{2} \cdot 6 \mathrm{H}_{2} \mathrm{O}$ of analytical reagent quality and distilled water. Magnesium chloride is deliquescent, and it is difficult to weigh out an amount containing an accurately known quantity of $\mathrm{MgCl}_{2}$. Because of this difficulty, the solutions were prepared in a weighed 1-liter volumetric flask, adjusting the compositions by trial and error until the desired densities were obtained. Densities for solutions of the desired concentrations were taken from density-concentration data for $\mathrm{MgCl}_{2}$ solutions in the International Critical Tables [9]. In order to reduce the $\mathrm{CO}_{2}$ concentration, the solutions were transferred to an Erlenmeyer flask and a stream of $\mathrm{CO}_{2}$-free air was introduced into each solution while boiling gently under a reflux condenser fitted with a $\mathrm{CO}_{2}$ absorption tube. After cooling and filtering if necessary, the solutions were stored in $1 / 3$ liter portions in tightly stoppered plastic bottles. It is estimated that water loss during boiling increased the concentration of $\mathrm{MgCl}_{2}$ in the solution by not more than 0.05 percent. Solutions were prepared containing 5, 10, 15, $22,27,32,37,42,47,52,57,62,67$, and 72 percent by weight of $\mathrm{MgCl}_{2} \cdot 6 \mathrm{H}_{2} \mathrm{O}$ respectively. Three series of mixtures in the system $\mathrm{MgO}-\mathrm{MgCl}_{2}-\mathrm{H}_{2} \mathrm{O}$ were made using the separate portions of these $\mathrm{MgCl}_{2}$ solutions.

The first series of mixtures consisted of metastable solutions of $\mathrm{MgO}$ prepared by shaking for $2 \mathrm{hr}$. a l-g. portion of freshly heated $\left(18 \mathrm{hr}\right.$ at $\left.400^{\circ} \mathrm{C}\right) \mathrm{MgO}$ of analytical reagent quality with a $1 / 3$-liter quantity of each of the 14 above mentioned magnesium chloride solutions. The mixtures were filtered several times if necessary to obtain clear solutions. Magnesium oxychloride began to precipitate after a few hours or days depending on the $\mathrm{MgCl}_{2}$ contents of the solutions.

The second series of mixtures was made in an attempt to approach equilibrium from undersaturation. After from 1 to 3 weeks, about half of the magnesium oxychloride precipitated from each of the metastable solutions was removed by filtration and transferred to the second 1/3-liter portion of the solution of the same nominal $\mathrm{MgCl}_{2}$ concentration as that in which the precipitate had formed. It was calculated that the change in $\mathrm{MgCl}_{2}$ concentration 
of the original solution caused by precipitation of the oxychloride compounds varied from +0.01 to -0.08 percent. This change was ignored in plotting the data shown hereafter and in discussing solutions of the same nominal concentration.

The third series of mixtures, also an attempt to approach equilibrium from undersaturation, was prepared by adding $0.33 \mathrm{~g}$ of $\mathrm{Mg}(\mathrm{OH})_{2}$ to the remaining $1 / 3$-liter portion of each of the $\mathrm{MgCl}_{2}$ solutions. The $\mathrm{Mg}(\mathrm{OH})_{2}$ was prepared by hydrating $\mathrm{MgO}$ for $72 \mathrm{hr}$ in distilled water on the steam bath with subsequent drying at $110^{\circ} \mathrm{C}$. A fourth series was prepared with new $\mathrm{MgCl}_{2}$ solutions using $1 \mathrm{~g}$ of $\mathrm{Mg}(\mathrm{OH})_{2}$ per $1 / 3$-liter portion of solution, in order to obtain material for heat-of-solution determination. Subsequently additional mixtures of $\mathrm{MgO}$ in solutions containing 34 and 36 percent of $\mathrm{MgCl}_{2} \cdot 6 \mathrm{H}_{2} \mathrm{O}$, respectively, were made for the same purpose.

The mixtures were stored in a constant-temperature room at $25^{\circ} \mathrm{C}$ and shaken daily during their early history. From time to time the alkalinity of the solutions was determined by titrating a $10-\mathrm{ml}$ pipetted sample of the supernatant liquid with 0.02 $N \mathrm{HCl}$, using phenolphthalein as an indicator. The $\mathrm{HCl}$ solution was standardized against a calcium hydroxide solution, the $\mathrm{CaO}$ content of which had been determined gravimetrically. The alkalinity was calculated to the equivalent $\mathrm{MgO}$ and is referred to as the $\mathrm{MgO}$ content of the solution throughout this paper. No implication is intended as to the state of the $\mathrm{MgO}$ in solution. X-ray diffraction patterns of the precipitates were obtained at the time the second series of mixtures was prepared and later for precipitates of special interest.

The precipitates were analyzed, sometimes after washing with alcohol and ether or acetone and drying for several hours at room temperature in a vacuum over $\mathrm{Cacl}_{2}$, and sometimes after merely pressing out the solution on filter paper. Total magnesium was determined by heating the sample slowly to $450^{\circ}$ to $500^{\circ} \mathrm{C}$ after the addition of a few drops of concentrated sulfuric acid and weighing as $\mathrm{MgSO}_{4}$. Chloride was determined gravimetrically by precipitation as $\mathrm{AgCl}$. From these data the equivalent $\mathrm{MgCl}_{2}$ and $\mathrm{MgO}$ were calculated, and water was taken by difference.

To furnish material for the study of the variation of the heat of solution of $3 \mathrm{Mg}(\mathrm{OH})_{2} \cdot \mathrm{MgCl}_{2} \cdot n \mathrm{H}_{2} \mathrm{O}$ with the change of water content, 4 liters of 58.5 percent $\mathrm{MgCl}_{2} \cdot 6 \mathrm{H}_{2} \mathrm{O}$ solution was shaken with $15 \mathrm{~g}$ of freshly calcined $\mathrm{MgO}$ and filtered. At the end of 3 months, the oxychloride compound which had precipitated was recovered by filtration, washed with alcohol and acetone, and dried under vacuum. Analyses, heat-of-solution determinations, and dehydration studies were made using this material. Samples were exposed at room temperature to air of various humidities in desiccators containing water, saturated solutions of $\mathrm{Na}_{2} \mathrm{Cr}_{2} \mathrm{O}_{7}, \mathrm{MgCl}_{2} \cdot 6 \mathrm{H}_{2} \mathrm{O}, \mathrm{KOH}$, or solid $\mathrm{Mg}\left(\mathrm{ClO}_{4}\right)_{2}$ respectively. Other samples were heated at $45^{\circ}, 110^{\circ}$, and $180^{\circ} \mathrm{C}$. The samples were weighed periodically to determine the loss or gain of water. Subsequently, their heats of solution in $\mathrm{HCl}, 26.61 \mathrm{H}_{2} \mathrm{O}\left(2.00 \mathrm{~N}\right.$ at $\left.25^{\circ} \mathrm{C}\right)$ were determined.

\subsection{Heat-of-Solution Measurements}

The heats of solution of the oxychloride precipitates were determined in $\mathrm{HCl} 26.61 \mathrm{H}_{2} \mathrm{O}$. The isothermal jacket calorimeter, described elsewhere [10], has been lined with platinum and is fitted with a four-blade platinum stirrer. The valve has been removed and the powdered samples are introduced by means of a funnel. Electrical calibration and calculations of the corrected temperature rise were performed by conventional methods [11].

\section{Results and Discussion}

\subsection{Precipitation of Magnesium Oxychloride}

The amount of $\mathrm{MgO}$ initially dissolved by $\mathrm{MgCl}_{2}$ solutions varies with the time and temperature of heating of the $\mathrm{MgO}$, with the concentration of the $\mathrm{MgCl}_{2}$ solution, with the ratio of $\mathrm{MgO}$ to $\mathrm{MgCl}_{2}$ solution, with the time of shaking, and, perhaps, with other factors. Using $\mathrm{MgO}$ from a single source, Lukens [2] has shown this variation in considerable detail for one particular concentration of $\mathrm{MgCl}_{2}$ solution. In the present work, only sufficient $\mathrm{MgO}$ was used to give metastable solutions containing 3 $\mathrm{g} /$ liter or less of $\mathrm{MgO}$, since solutions containing substantially more than this amount thickened to a gel upon precipitation of the oxychloride compounds. Under the conditions chosen, $3 \mathrm{~g}$ of solid $\mathrm{MgO}$ per liter of solution and $2 \mathrm{hr}$ of shaking before filtration, solutions containing 27 percent or more of $\mathrm{MgCl}_{2} \cdot 6 \mathrm{H}_{2} \mathrm{O}$ dissolved nearly all of the $\mathrm{MgO}$. There were some variations in $\mathrm{MgO}$ content of the clear solutions, indicating perhaps that $2 \mathrm{hr}$ was not the optimum shaking time, but all of these solutions after filtration contained from 20 to 40 times the concentration reached subsequently upon standing for 7 months. The solutions containing 22, 15, 10 percent of $\mathrm{MgCl}_{2} \cdot 6 \mathrm{H}_{2} \mathrm{O}$ dissolved substantially less $\mathrm{MgO}$, but even these after filtering contained 10 or more times the final concentration. The solution containing 5 percent of $\mathrm{MgCl}_{2} \cdot 6 \mathrm{H}_{2} \mathrm{O}$ dissolved very little $\mathrm{MgO}$.

The equivalent $\mathrm{MgO}$ content of magnesium chloride solutions shaken with $\mathrm{Mg}(\mathrm{OH})_{2}$ depended on the relative amounts of $\mathrm{Mg}(\mathrm{OH})_{2}$ and solution and upon the time of contact, as well as upon the concentration of $\mathrm{MgCl}_{2}$. Many of the solutions of the series shaken with $1 \mathrm{~g}$ of $\mathrm{Mg}(\mathrm{OH})_{2}$ per liter of solution dissolved it slowly, reaching maximum $\mathrm{MgO}$ concentration in about 2 weeks. These solutions were metastable, and subsequently with the precipitation of magnesium oxychloride the concentration of $\mathrm{MgO}$ fell, approaching the final value reached by the other solutions of the same $\mathrm{MgCl}_{2}$ content. This behavior was characteristic of the solutions containing 37 percent or more of $\mathrm{MgCl}_{2} \cdot 6 \mathrm{H}_{2} \mathrm{O}$. The solutions of less $\mathrm{MgCl}_{2}$ content did not become greatly supersaturated, but slowly approached a final $\mathrm{MgO}$ concentration depending on the amount of $\mathrm{MgCl}_{2}$ in solution. The magnesium chloride solutions shaken with $3 \mathrm{~g}$ of $\mathrm{Mg}(\mathrm{OH})_{2}$ per liter behaved similarly, 
except that the maximum $\mathrm{MgO}$ concentrations were generally higher and more quickly attained.

The changes of the $\mathrm{MgO}$ concentration of the solutions containing 47 percent $\mathrm{MgCl}_{2} \cdot 6 \mathrm{H}_{2} \mathrm{O}$ are plotted in figure 1 as a function of time. The changes occurring in these solutions are typical of those found with the other solutions of such $\mathrm{MgCl}_{2}$ concentration that oxychloride compounds were formed. The original supersaturated clear solution contained $3.02 \mathrm{~g} \mathrm{MgO}$ per liter. In 13 days, precipitation of magnesium oxychloride reduced the concentration to $0.073 \mathrm{~g}$ $\mathrm{MgO}$ per liter, where it remained for more than 6 months. At 16 days about half of the precipitate formed was transferred to a fresh solution of the same $\mathrm{MgCl}_{2}$ concentration. The $\mathrm{MgO}$ concentration of this solution, which, at 1 day, was $0.135 \mathrm{~g} /$ /iter, was reduced in 5 days to 0.107 and in 9 days to 0.068 $\mathrm{g} /$ liter where it remained within experimental error. The possible significance of the 1-day value will be discussed later.

One-third gram of solid magnesium hydroxide suspended in $1 / 3$ liter of 47 -percent $\mathrm{MgCl}_{2} \cdot 6 \mathrm{H}_{2} \mathrm{O}$ solution gave an $\mathrm{MgO}$ concentration of $0.132 \mathrm{~g}$ /liter in 1 day, and $1 \mathrm{~g}$ under the same conditions gave a concentration of $0.386 \mathrm{~g} \mathrm{MgO}$ per liter. In the first solution, additional $\mathrm{Mg}(\mathrm{OH})_{2}$ dissolved, raising the $\mathrm{MgO}$ concentration to $0.233 \mathrm{~g} /$ liter in 15 days. Thereafter precipitation of magnesium oxychloride reduced the concentration to $0.080 \mathrm{~g} /$ liter at 51 days and $0.063 \mathrm{~g} /$ liter at 219 days. In the second solution, the $\mathrm{MgO}$ concentration remained near the 1-day value for about a week, and then decreased to 0.109 $\mathrm{g} /$ liter at 21 days and to $0.078 \mathrm{~g} /$ liter at 43 days. It remained essentially constant thereafter until the precipitate was removed for analysis at 156 days.

In figure 2 are plotted the concentrations of $\mathrm{MgO}$ in the $\mathrm{MgCl}_{2}$ solutions when the experiments were terminated at about 7 months. This figure represents the $25^{\circ} \mathrm{C}$ isotherm of the system $\mathrm{MgO}-\mathrm{MgCl}_{2} \cdot 6 \mathrm{H}_{2} \mathrm{O}$ $\mathrm{H}_{2} \mathrm{O}$ with the $\mathrm{MgO}$ scale greatly expanded. A vertical line $\mathrm{T}-\mathrm{T}$ is drawn through the concentration of $\mathrm{MgCl}_{2} \cdot 6 \mathrm{H}_{2} \mathrm{O}\left(10.89 \%\right.$ of $\left.\mathrm{MgCl}_{2}\right)$ given by Bury

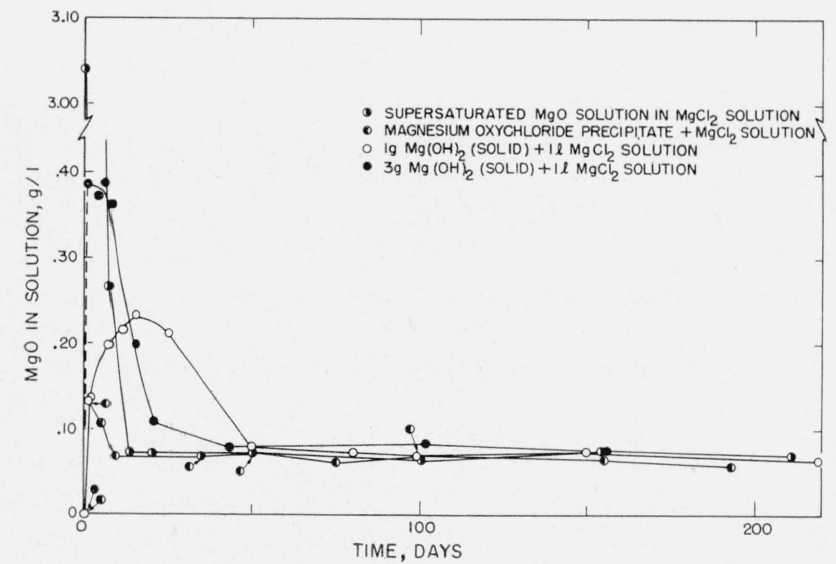

Figure 1. Concentration-time relationship of $\mathrm{MgO}$ in $\mathrm{MgCl}_{2}$ solution.

Concentration of $\mathrm{MgCl}_{2}$ solution, 47 percent of $\mathrm{MgCl}_{2} \cdot 6 \mathrm{H}_{2} \mathrm{O}$. $\quad\left(22 \%\right.$ of $\mathrm{MgCl}_{2}$, equivalent to $23.6^{\circ} \mathrm{B}$.) and Davies [4a] as the triple point at which magnesium chloride solution, $\mathrm{Mg}(\mathrm{OH})_{2}$, and $3 \mathrm{Mg}(\mathrm{OH})_{2} \cdot-$ $\mathrm{MgCl}_{2} \cdot 8 \mathrm{H}_{2} \mathrm{O}$ coexist. The data of Robinson and Waggaman [1] are represented by the open squares, and the solubility of $\mathrm{Mg}(\mathrm{OH})_{2}$ in pure water at $30^{\circ} \mathrm{C}$ [15] is also shown. Chassevent's value of 0.030 $\mathrm{g} /$ liter for the solubility of magnesium oxide in magnesium chloride solution [3] is plotted in figure 2 as an open triangle.

$A$ second vertical line $\mathrm{X}-\mathrm{X}$ is drawn in figure 2 separating the diagram in two regions. To the right of this line the final precipitates were, with two exceptions, $3 \mathrm{Mg}(\mathrm{OH})_{2} \cdot \mathrm{MgCl}_{2} \cdot 8 \mathrm{H}_{2} \mathrm{O}$, and to the left, with three exceptions, they were $\mathrm{Mg}(\mathrm{OH})_{2}$. The exceptions are indicated in the figure by the letters $\mathrm{A}, \mathrm{B}$, and $\mathrm{M}$ attached to the various points and indicating the presence of $3 \mathrm{Mg}(\mathrm{OH})_{2} \cdot \mathrm{MgCl}_{2} \cdot 8 \mathrm{H}_{2} \mathrm{O}$, $5 \mathrm{Mg}(\mathrm{OH})_{2} \cdot \mathrm{MgCl}_{2} \cdot 8 \mathrm{H}_{2} \mathrm{O}$, and $\mathrm{Mg}(\mathrm{OH})_{2}$ respectively. The line $\mathrm{X}-\mathrm{X}$ makes the same separation for the results of Robinson and Waggaman and thus indicates the approximate location of the triple point $\mathrm{Mg}(\mathrm{OH})_{2}-3 \mathrm{Mg}(\mathrm{OH})_{2} \cdot \mathrm{MgCl}_{2} \cdot 8 \mathrm{H}_{2} \mathrm{O}$ solution for their work as well as for the author's.

In the present work it was planned to approach equilibrium from both directions. Because $\mathrm{Mg}(\mathrm{OH})_{2}$, contrary to statements in the literature, formed supersaturated solutions, the approach from undersaturation was not accomplished with certainty when $\mathrm{Mg}(\mathrm{OH})_{2}$ was added to $\mathrm{MgCl}_{2}$ solutions. In every case the concentration of $\mathrm{MgO}$ in these solutions passed through a maximum within a few days after the $\mathrm{Mg}(\mathrm{OH})_{2}$ had been added. With solutions containing 27 percent or less of $\mathrm{MgCl}_{2} \cdot 6 \mathrm{H}_{2} \mathrm{O}$, the final concentrations of $\mathrm{MgO}$ were equal to or

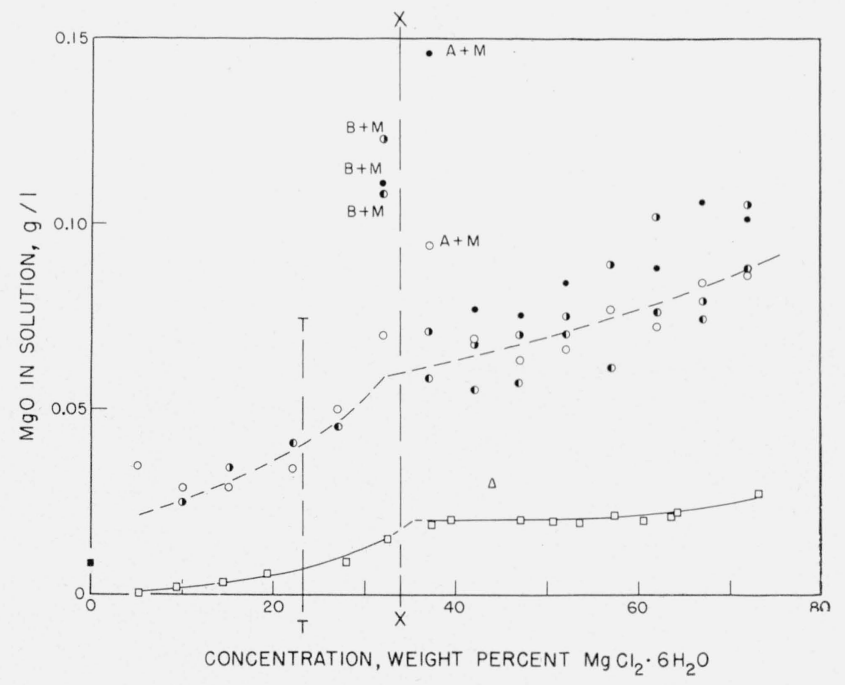

Figure 2. Equivalent concentration of $\mathrm{MgO}$ in $\mathrm{MgCl}$. solutions at $25^{\circ} \mathrm{C}$. Precipitated from metastable solution of $\mathrm{MgO}_{\text {in }} \mathrm{MgCl}_{2}$ solution; $\mathbf{O}$, pre-
cipitate from metastable solution added to fresh $\mathrm{MgCl}_{2}$ solution; $0,1 \mathrm{~g} / 1$ of solid cipitate from metastable solution added to fresh $\mathrm{MgCl}_{2}$ solution; $\mathrm{O}, 1 \mathrm{~g} / 1$ of solid
$\mathrm{Mg}(\mathrm{OH})_{2}$ suspended in $\mathrm{MgCl}_{2}$ solution;, $3 \mathrm{~g} / 1$ of solid $\mathrm{Mg}(\mathrm{OH})_{2}$ suspended in $\mathrm{Mg}(\mathrm{OH})_{2}$ suspended in $\mathrm{MgCl}_{2}$ solution;, $3 \mathrm{~g} / 1$ of solid $\mathrm{Mg}(\mathrm{OH})_{2}$ suspended in
$\mathrm{MgCl}_{2}$ solution; $\square$, Robinson and Waggaman solubility data [1]; , solubility of $\mathrm{Mg}(\mathrm{OH})_{2}$ in pure water [15]; $\triangle$, Chassevent solubility data [3]; A, solid phase $3 \mathrm{Mg}(\mathrm{OH})_{2} \cdot \mathrm{MgCl}_{2} \cdot 8 \mathrm{H}_{2} \mathrm{O} ; \mathrm{B}$, solid phase $5 \mathrm{Mg}(\mathrm{OH})_{2} \cdot \mathrm{MgCl}_{2} \cdot 8 \mathrm{H}_{2} \mathrm{O} ; \mathrm{C}$, solid phase $\mathrm{Mg}(\mathrm{OH})_{2}$. 
greater than the early maxima. Thus, over the range 10 to 27 percent $\mathrm{MgCl}_{2} \cdot 6 \mathrm{H}_{2} \mathrm{O}$ apparent equilibrium was approached from both directions. At higher concentrations, however, it was not approached from undersaturation even in solutions to which precipitated magnesium oxychloride had been added. For these solutions the same sort of early maximum was found in the curves of concentration versus time as for the solutions to which $\mathrm{Mg}(\mathrm{OH})_{2}$ had been added. The final concentration was greater than the early maximum only for the solution containing 57 percent of $\mathrm{MgCl}_{2} \cdot 6 \mathrm{H}_{2} \mathrm{O}$. In this solution the final concentration was approached both from underand from supersaturation, the usual criterion for equilibrium. In spite of this approach, the final concentration. was substantially higher than that reported by Robinson and Waggaman.

Both Bury and Davies and Robinson and Waggaman shook their mixtures continuously whereas in. the present work the mixtures were shaken only occasionally. The former authors attribute the higher concentration found for the triple point by Robinson and Waggaman to the formation of metastable substances but state that this formation is less likely to occur in the absence of shaking. In. a subsequent paper on the system $\mathrm{MgO}-\mathrm{CaO}-\mathrm{MgCl}_{2}$ $\mathrm{H}_{2} \mathrm{O}$ [4b] Bury and Davies state that continuous shaking is necessary to attain equilibrium in that system. The author can make no comment on the differing concentrations indicated for the triple point but considers that the scatter of the points and the generally higher solubilities obtained in the present work indicate that equilibrium was not attained in. the absence of continuous shaking in spite of the duration and manner of approach.

The results of X-ray examination of the precipitates are given in table 1. Except in three instances, the final precipitates were $\mathrm{Mg}(\mathrm{OH})_{2}$ or $3 \mathrm{Mg}(\mathrm{OH})_{2}$. $\mathrm{MgCl}_{2} \cdot 8 \mathrm{H}_{2} \mathrm{O}$. The compound $5 \mathrm{Mg}(\mathrm{OH})_{2} \cdot \mathrm{MgCl}_{2}$. $8 \mathrm{H}_{2} \mathrm{O}$ was the first formed in a number of solutions and appeared as an intermediate phase in several instances when $\mathrm{Mg}(\mathrm{OH})_{2}$ was placed in contact with $\mathrm{MgCl}_{2}$ solution. The rate of conversion to $3 \mathrm{Mg}(\mathrm{OH})_{2} \cdot \mathrm{MgCl}_{2} \cdot 8 \mathrm{H}_{2} \mathrm{O}$ appears to increase with increase in the concentration of magnesium chloride in solution. The 5:1 oxychloride was not present (according to the X-ray patterns) at 1 day in the more concentrated $\mathrm{MgCl}_{2}$ solutions and remained at 7 months in the most dilute in which it was formed. Lukens [2] found that in 71-percent $\mathrm{MgCl}_{2} \cdot 6 \mathrm{H}_{2} \mathrm{O}$ solutions the 5:1 compound formed first, and Feitknecht and Held [6] found it was that precipitated first and subsequently converted to the $3: 1$ compound at all concentrations above about 27.8 percent of $\mathrm{MgCl}_{2} \cdot 6 \mathrm{H}_{2} \mathrm{O}$. In the present work when the oxychloride precipitates were transferred to fresh solutions containing no $\mathrm{MgO}$, these solutions became supersaturated (in terms of $\mathrm{MgO}$ ) with respect to their final concentrations. This initial supersaturation may be an indication that $5 \mathrm{Mg}(\mathrm{OH})_{2} \cdot \mathrm{MgCl}_{2}$. $8 \mathrm{H}_{2} \mathrm{O}$ was still present at the time of transfer even. in the precipitates from the three most concentrated magnesium chloride solutions where the X-ray pat-
TABLE 1. X-ray identification of solid phases found in contact with magnesium chloride solutions

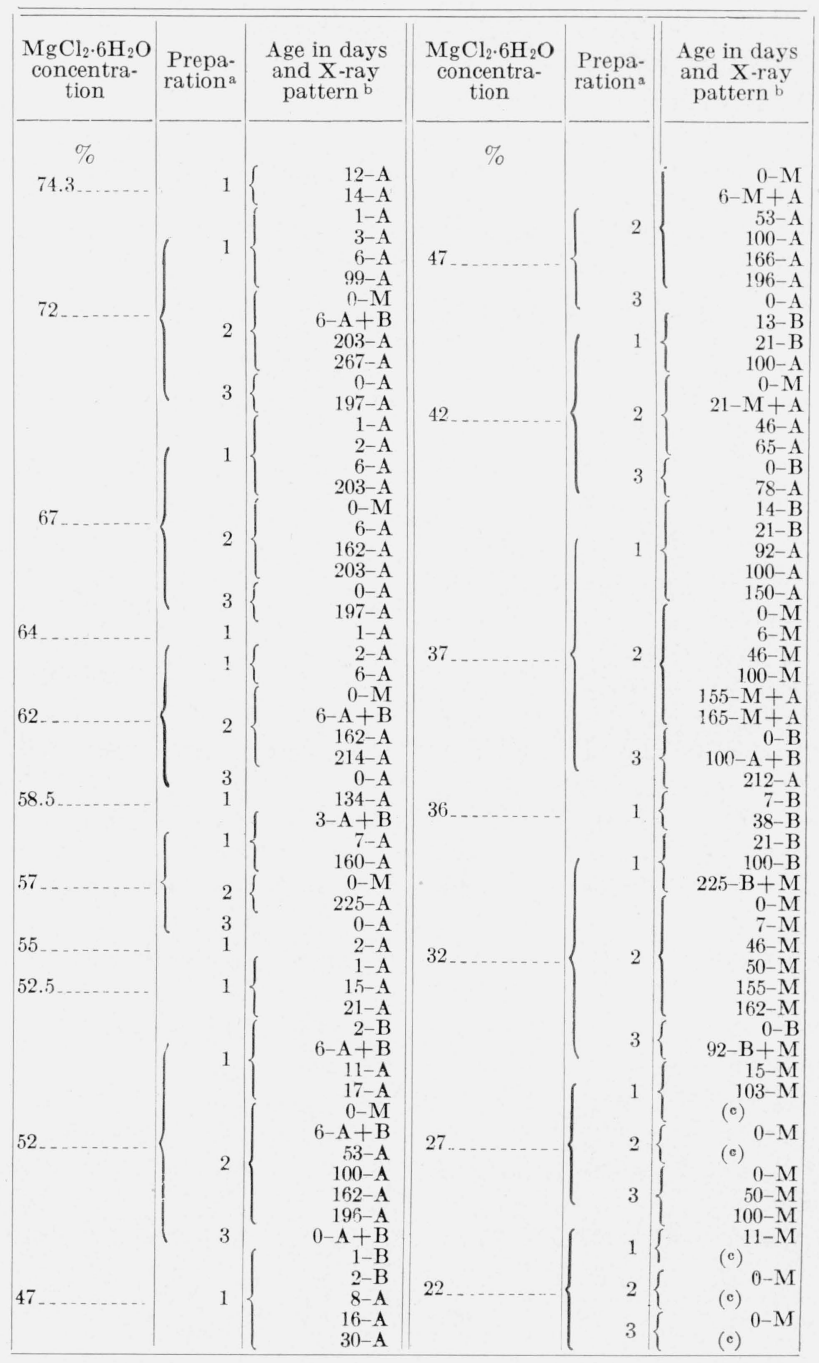

2Preparation 1 , made by shaking $1 \mathrm{~g}$ of freshly calcined MgO with $1 / 3$ liter 0 $\mathrm{MgCl}_{2}$ solution; 2 , made by adding $0.3 \mathrm{~g}$ of $\mathrm{Mg}(\mathrm{OH})_{2}$ to $1 / 3$ liter of $\mathrm{MgCl}_{2}$ solution and 3 , made by transferring about half of the precipitate from companion prepara tion 1 to a MgO-free solution.

tion 1 to a MgO-free solution. time the X-ray sample was taken. The letter following the dash represents the compound indicated by the $\mathrm{X}$-ray pattern. $\mathrm{A}=3 \mathrm{Mg}(\mathrm{OH})_{2} \cdot \mathrm{MgCl}_{2} \cdot 8 \mathrm{H}_{2} \mathrm{O}$, $\mathrm{B}=5 \mathrm{Mg}(\mathrm{OH})_{2} \cdot \mathrm{MgCl}_{2} \cdot 8 \mathrm{H}_{2} \mathrm{O}, \mathrm{M}=\mathrm{Mg}(\mathrm{OH})_{2}$.

c At the end of the experiments these precipitates were judged by inspection to contain only $\mathrm{Mg}(\mathrm{OH})_{2}$ because of the difference between their appearance and that of the bulky slow-settling magnesium oxychlorides. X-ray patterns and heats of solution were not obtained.

terns did not indicate its occurrence. 'There appears, however, to be no concentration range in which the 5:1 oxychloride is the stable compound in equilibrium with magnesium chloride solution.

\subsection{Heats of Dilution of $\mathrm{MgCl}_{2}$ Solutions}

In order to obtain data for correcting the observed heats of solution of samples containing magnesium chloride solution, heat-of-dilution experiments were performed. Magnesium chloride solutions of various strengths were added in small quantities to $600 \mathrm{~g}$. of 
$\mathrm{HCl}, 26.61 \mathrm{H}_{2} \mathrm{O}$ to which had previously been added $1 \mathrm{~g}$ of $\mathrm{MgO}$ (equivalent to 0.02 moles $\mathrm{MgO}$ per mole $\mathrm{HCl}$ ). The data are summarized in table 2. The precision of the data was not adequate to establish the variation of the heat of dilution with variation in the quantity of $\mathrm{MgCl}_{2}$ solution used. Therefore, only the average values are given in the table.

\section{TABLe 2. Heat of dilution}

These data represent the heat effect of adding $\mathrm{MgCl}_{2}$ solutions of various strengths to $\mathrm{HCl}, 26.61 \mathrm{H}_{2} \mathrm{O}$ to which $0.02 \mathrm{~mol} \mathrm{MgO}$ per mol of $\mathrm{HCl}$ had previously been added.

\begin{tabular}{|c|c|c|c|}
\hline \multicolumn{2}{|c|}{$\begin{array}{l}\text { Composition of } \\
\mathrm{MgCl}_{2} \text { solution }\end{array}$} & \multirow{2}{*}{$\begin{array}{l}\text { Range of dilu- } \\
\text { tion ratio, } \mathrm{R} \\
\begin{array}{l}\mathrm{mol} \mathrm{MgCl}_{2} \text { per } \\
\mathrm{mol} \mathrm{HCl}^{-} \mathrm{HCl}\end{array}\end{array}$} & \multirow{2}{*}{$\begin{array}{c}\begin{array}{c}\text { Heat of } \\
\text { dilution, } \\
-\Delta \mathrm{H} 298^{\circ} \mathrm{C} \\
\mathrm{kcal} / \mathrm{mol} \\
\mathrm{MgCl}_{2}\end{array}\end{array}$} \\
\hline $\begin{array}{l}\text { Percent } \\
\mathrm{MgCl}_{2}\end{array}$ & $\underset{\mathrm{MgCl}_{2}}{\mathrm{~mol}_{2} \mathrm{O}}$ & & \\
\hline $\begin{array}{l}35.1 \\
24.1 \\
20.7 \\
16.6\end{array}$ & $\begin{array}{r}9.77 \\
16.64 \\
20.25 \\
25.56\end{array}$ & $\begin{array}{r}0.012 \text { to } 0.060 \\
.008 \text { to } .037 \\
.006 \text { to } .032 \\
.005 \text { to } .024\end{array}$ & $\begin{array}{r}2.33 \\
0.79 \\
.56 \\
.22\end{array}$ \\
\hline
\end{tabular}

Measurements were made in duplicate at each of three dilution ratios for each solution. The standard deviation of a single determination was $0.07 \mathrm{kcal} / \mathrm{mol}$ $\mathrm{MgCl}_{2}$, caleulated by the formula.

$$
\mathrm{S}=\sqrt{\frac{\sum\left(\Delta \mathrm{H}_{1}-\Delta \mathrm{H}_{2}\right)^{2}}{24}}
$$

where $\Delta \mathrm{H}_{1}$ and $\Delta \mathrm{H}_{2}$ are the duplicate measurements. No significant values of $\mathrm{d}(-\Delta \mathrm{H}) / \mathrm{dR}$ could be calculated from these data. Therefore, only the average value for each concentration is given.

\subsection{Heats of Solution}

\section{a. $3 \mathrm{Mg}(\mathrm{OH})_{2} \cdot \mathrm{MgCl}_{2} \cdot n \mathrm{H}_{2} \mathrm{O}$}

Magnesium oxychloride having the ratio three $\mathrm{Mg}(\mathrm{OH})_{2}$ to one $\mathrm{MgCl}_{2}$ is the stable form in equilibrium with solutions in which an oxychloride is formed. This material could be filtered from the solution and washed with alcohol and ether without change in the X-ray pattern. Consequently most of the analyses and heat-of-solution measurements were performed on samples so treated. A few samples were prepared without washing, however, by removing as much $\mathrm{MgCl}_{2}$ solution as possible by pressing. The results of the analyses and the heats of solution are given in table 3. The unwashed samples are indicated by the letter $\mathrm{P}$ and contain excess $\mathrm{MgCl}_{2}$ solution as shown by the analyses.

Since the amount of material was limited, generally only one heat-of-solution determination was made on each sample. However, replicate determinations were made in a number of instances with a precision (standard deviation of a single test) of $\pm 1.15 \mathrm{cal} / \mathrm{g}(1 \mathrm{cal}=4.1840 \mathrm{abs} \mathrm{j})$.

The heat of solution of magnesium oxychloride was calculated from the data in table 3 . It was assumed that $\mathrm{Mg}(\mathrm{OH})_{2}$ was present in excess in samples having a ratio $\mathrm{Mg}(\mathrm{OH})_{2} / \mathrm{MgCl}_{2}$ greater than three and that $\mathrm{MgCl}_{2} \cdot 6 \mathrm{H}_{2} \mathrm{O}$ was present in samples having a smaller ratio. The first condition would be caused by the removal of $\mathrm{MgCl}_{2}$ from the precipitated oxychloride by too vigorous washing.
TABLE 3. Heats of solution of $3 \mathrm{Mg}(\mathrm{OH})_{2} \cdot \mathrm{MgCl}_{2} \cdot \mathrm{H}_{2} \mathrm{O}$ preparations in $\mathrm{HCl}, 26.61 \mathrm{H}_{2} \mathrm{O}$

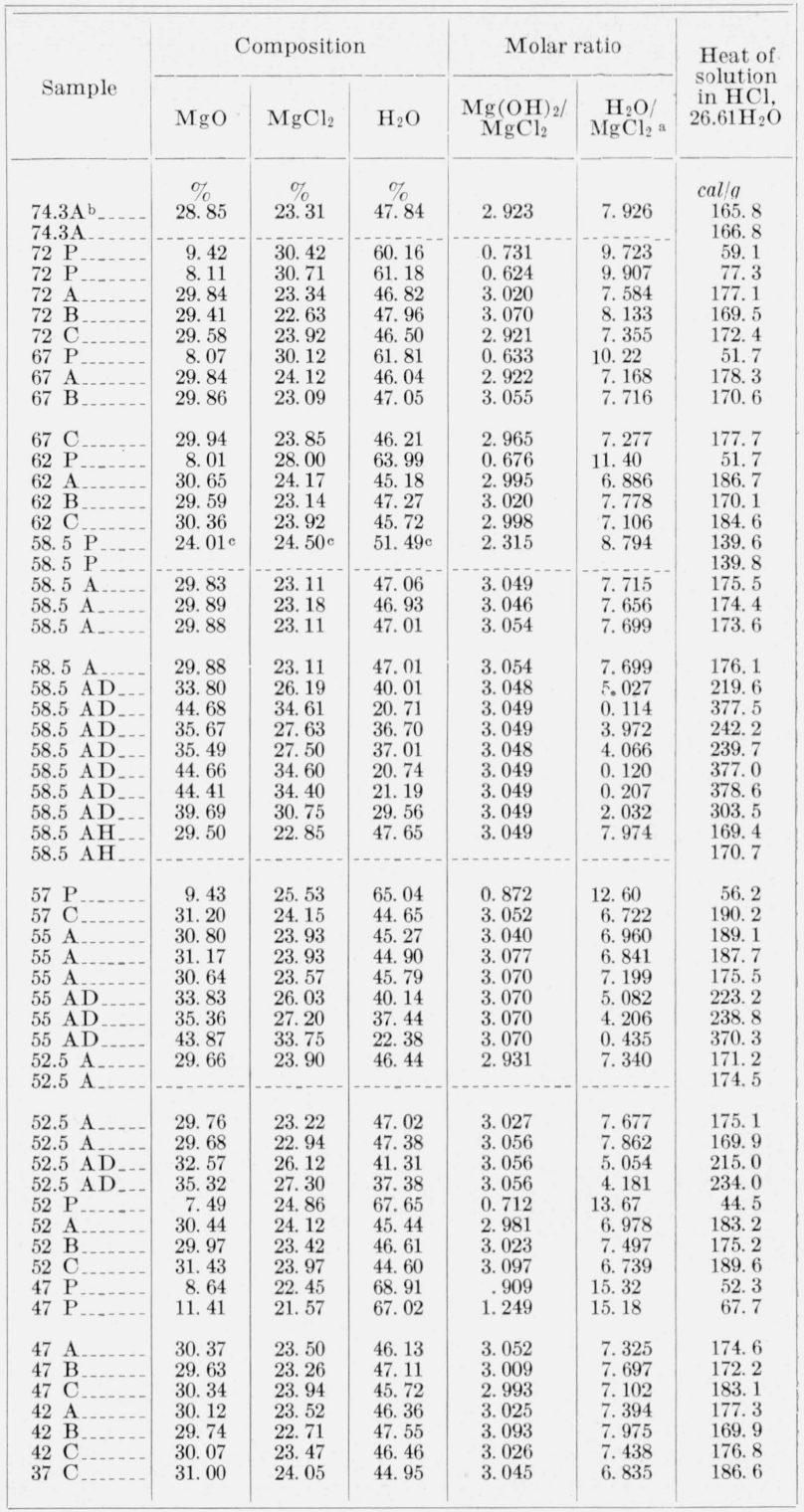

a Corrected for water equivalent to $\mathrm{MgO}$ to form $\mathrm{Mg}(\mathrm{OH})_{2}$

b 74.3 , etc., equals original percent of $\mathrm{MgCl}_{2} \cdot 6 \mathrm{H}_{2} \mathrm{O}$ by weight in the solution from which the sample was obtained. A, Precipitated from clear metastable solution of $\mathrm{MgO}$ in $\mathrm{MgCl}_{2}$ solution. Washed with alcohol and ether. $\mathrm{B}, \mathrm{Re}-$ action product of $\mathrm{Mg}(\mathrm{OH})_{2}$ and $\mathrm{MgCl}_{2}$ solution. Washed with alcohol and ether. C, Precipitate A placed in fresh $\mathrm{MgCl}_{2}$ solution containing no dissolved ether. $\mathrm{C}$, Precipitate A placed in fresh $\mathrm{MgCl}_{2}$ solution containing no dissolved
$\mathrm{MgO}$. Washed with alcohol and ether. P, Precipitated as in $\mathrm{A} . \mathrm{MgCl}_{2}$ solution removed by pressure. Precipitate not washed.

$\mathrm{H}$, Equilibrated over saturated solution of $\mathrm{Na}_{2} \mathrm{Cr}_{2} \mathrm{O}_{7}$. $\mathrm{MgO}= \pm 0.027$ percent, for $\mathrm{MgCl}_{2}= \pm 0.032$ percent.

The second condition would be caused (under the conditions of drying) by inadequate washing so that the sample retained magnesium chloride solution. The observed heats of solution were corrected using $26.88 \mathrm{kcal} / \mathrm{mole}$ [12] for the heat of solution of excess $\mathrm{Mg}(\mathrm{OH})_{2}$ and $1.65 \mathrm{kcal} / \mathrm{mole}$ (determined in this work) for the heat of solution of $\mathrm{MgCl}_{2} \cdot 6 \mathrm{H}_{2} \mathrm{O}$. The total water was corrected for that in the $\mathrm{MgCl}_{2} \cdot 6 \mathrm{H}_{2} \mathrm{O}$ or $\mathrm{Mg}(\mathrm{OH})_{2}$ and the corrected value taken as $n$ in 
the formula $3 \mathrm{Mg}(\mathrm{OH})_{2} \cdot \mathrm{MgCl}_{2} \cdot n \mathrm{H}_{2} \mathrm{O}$ for the oxychloride.

The calculated heats of solution for the oxychloride samples are shown in figure 3 where they are plotted in kilocalories per mole of $\mathrm{MgCl}_{2}$ (equivalent to per mole of $\left.3 \mathrm{Mg}(\mathrm{OH})_{2} \cdot \mathrm{MgCl}_{2} \cdot n \mathrm{H}_{2} \mathrm{O}\right)$ against the value of $n$. The standard deviations of the individual tests calculated from the relatively few replicate measurements are $\pm 0.48 \mathrm{kcal} / \mathrm{mole}$ for the heat of solution and \pm 0.026 for the value of $n$.

The straight lines in figure 3 were calculated by the method of least squares from the data in the range of values of $n$ from 0 to 4 for one line and from 4 to 8 for the other. Values near $n=4$ were used for both lines. The data as a whole could be represented by a single curved line. However, the grouping shown would be explained if the samples were composed of three oxychlorides containing 8,4 , and 0 moles of water respectively per mole of $\mathrm{MgCl}_{2}$. In the dehydration experiments there was evidence of a hydrate containing four molecules of water, since the material heated at $110^{\circ} \mathrm{C}$ tended to reach and remain at that composition, as did material heated at $45^{\circ}$ C. A washed sample of magnesium oxychloride kept over saturated solution of $\mathrm{MgCl}_{2}$ (relative humidity 33 percent [9]) attained the composition $3 \mathrm{Mg}(\mathrm{OH})_{2} \cdot \mathrm{MgCl}_{2} \cdot 7.859 \mathrm{H}_{2} \mathrm{O}$. When the sample was transferred to a desiccator containing a saturated solution of $\mathrm{Na}_{2} \mathrm{Cr}_{2} \mathrm{O}_{7}$ (relative humidity $52 \%$ [13]) the composition became $3 \mathrm{Mg}(\mathrm{OH})_{2}$. $\mathrm{MgCl}_{2} \cdot 7.974 \mathrm{H}_{2} \mathrm{O}$.

It should be pointed out that the dehydration of certain samples was arbitrarily stopped when the composition reached approximately 5 and 2 molecules of water per mole of $3 \mathrm{Mg}(\mathrm{OH})_{2} \cdot \mathrm{MgCl}_{2}$ in order to secure the heats of solution of samples containing those amounts of water. On the other hand, the composition at 4 molecules of water was reached in 1 day by samples heated at $110^{\circ} \mathrm{C}$ whereas further heating at that temperature for several days resulted in very little further loss of water. The dehydration of $3 \mathrm{Mg}(\mathrm{OH})_{2} \cdot \mathrm{MgCl}_{2} \cdot 8 \mathrm{H}_{2} \mathrm{O}$ over $\mathrm{KOH}$ and magnesium perchlorate did not show with certainty the existence of other hydrates.

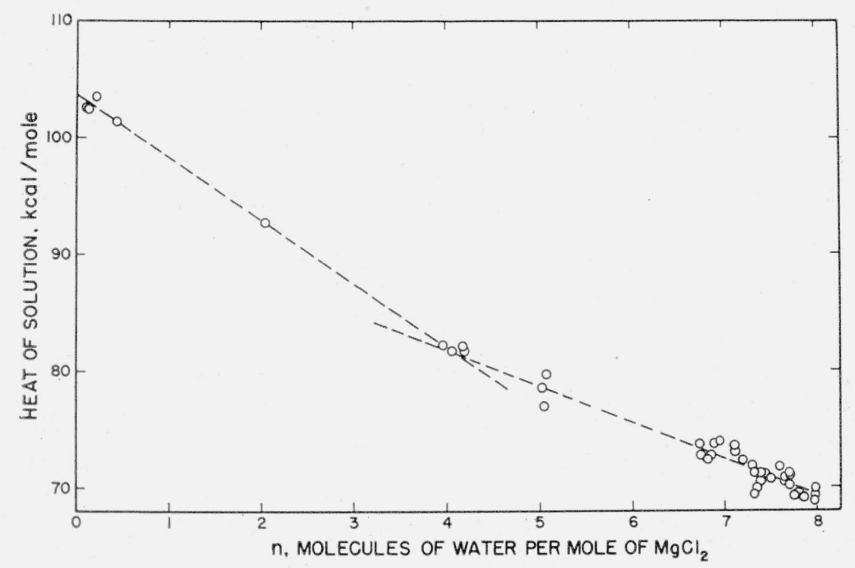

FigueE 3. The heat of solution of $3 \mathrm{Mig}(\mathrm{OH})_{2} \cdot \mathrm{NigCl}_{2} \cdot n \mathrm{H}_{2} \mathrm{O}$ in $\mathrm{HCl}$. $26.61 \mathrm{H}_{2} \mathrm{O}$ at $25^{\circ} \mathrm{C}$.
The author believes that the oxychloride as precipitated contains 8 molecules of water in agreement with the composition $2 \mathrm{MgO} \cdot \mathrm{HCl} \cdot 5 \mathrm{H}_{2} \mathrm{O}$ (equivalent to $\left.3 \mathrm{Mg}(\mathrm{OH})_{2} \cdot \mathrm{MgCl}_{2} \cdot 8 \mathrm{H}_{2} \mathrm{O}\right)$ given by Robinson and Waggaman [1] from analyses of unwashed precipitates and of the solutions in which they formed. (Their reported composition $3 \mathrm{MgO} \cdot \mathrm{MgCl}_{2} \cdot 10 \mathrm{H}_{2} \mathrm{O}$ seems to be erroneously converted from their determined composition of $2.02 \mathrm{MgO} \cdot \mathrm{HCl} \cdot 5.04 \mathrm{H}_{2} \mathrm{O}$.) Part of this water is removed when the precipitated material is prepared for analysis, and samples are obtained containing from 7 to 8 molecules of water as given in table 3. Feitknecht and Held [6] prepared materials containing $7,5.14,3.4$, or 0.15 molecules of water per mole of $3 \mathrm{Mg}(\mathrm{OH})_{2} \cdot \mathrm{MgCl}_{2}$ by drying the precipitated oxychloride. Wehner [14], who also concluded that the precipitated form contained 8 molecules of water, found that an air-dried sample originally containing 10 molecules of water contained 7 after drying for 30 min at $80^{\circ} \mathrm{C}, 4.7$ after drying at $120^{\circ} \mathrm{C}$ for $1 \mathrm{hr}$, and 3.1 molecules after $5 \mathrm{hrs}$ at $120^{\circ} \mathrm{C}$. After drying for $5 \mathrm{hrs}$ at $200^{\circ} \mathrm{C}$, the material was anhydrous. The differential thermal analysis [19] obtained in the present work and shown in figure 4 indicates the loss of water in three steps $\mathrm{A}, \mathrm{B}$, and $\mathrm{C}$ at $140^{\circ}, 165^{\circ}$, and $210^{\circ} \mathrm{C}$, respectively. The other deflections in this curve at higher temperatures represent the further stepwise decompositions of $3 \mathrm{Mg}(\mathrm{OH})_{2} \cdot \mathrm{MgCl}_{2}$ to the final solid product of $\mathrm{MgO}$. If hydrates other than that containing four molecules of water were formed during the dehydration of the precipitated oxychloride, however, the heat-of-solution measurements shown in figure 3 were not precise enough to reveal their presence.

From the equations for the straight lines in figure 3 , the following heats of solution in $\mathrm{HCl}, 26.61 \mathrm{H}_{2} \mathrm{O}$ were calculated:

$3 \mathrm{Mg}(\mathrm{OH})_{2} \cdot \mathrm{MgCl}_{2}, 103.96 \mathrm{kcal} / \mathrm{mole}$

$3 \mathrm{Mg}(\mathrm{OH})_{2} \cdot \mathrm{MgCl}_{2} \cdot 4 \mathrm{H}_{2} \mathrm{O}, 81.43 \mathrm{kcal} / \mathrm{mole} ;$

$3 \mathrm{Mg}(\mathrm{OH})_{2} \cdot \mathrm{MgCl}_{2} \cdot 7 \mathrm{H}_{2} \mathrm{O}, 72.54 \mathrm{kcal} / \mathrm{mole}$; $3 \mathrm{Mg}(\mathrm{OH})_{2} \cdot \mathrm{MgCl}_{2} \cdot \mathrm{H}_{2} \mathrm{O}, 69.61 \mathrm{kcal} /$ mole.

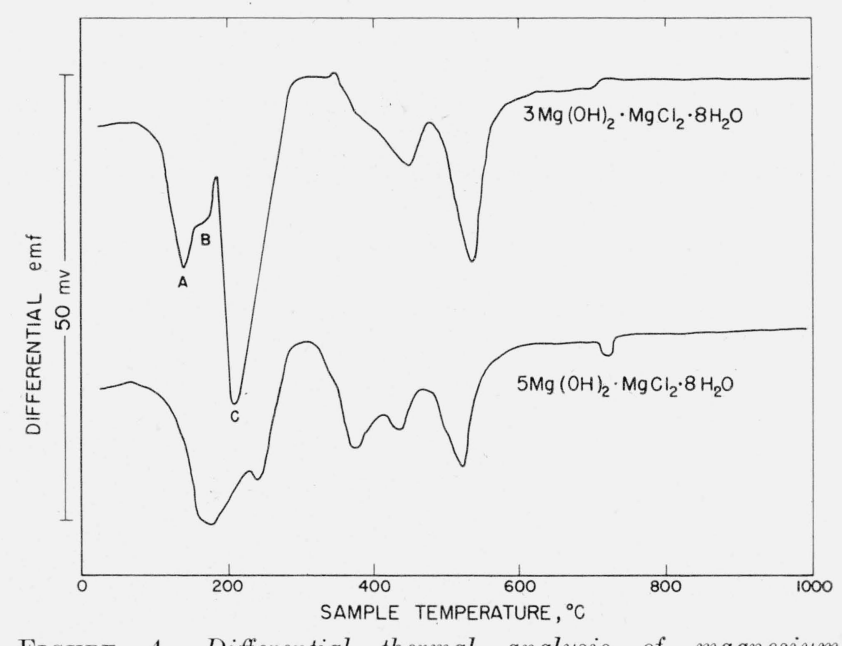

Figure 4. Differential thermal analysis of magnesium oxychlorides. 
The heats of solution of the pressed samples, the crystals of which presumably were $3 \mathrm{Mg}(\mathrm{OH})_{\Sigma}$. $\mathrm{MgCl}_{2} \cdot 8 \mathrm{H}_{2} \mathrm{O}$, agreed reasonably well with the value taken from figure 3. Corrected for the heat of dilution of the appropriate quantity of the $\mathrm{MgCl}_{2}$ solution from which the precipitates were taken, heats of solution of $69.29,(72.96), 70.74, \quad(72.96), 69.94$, $70.04,69.31,69.07,69.88$, and $70.97 \mathrm{kcal} /$ mole were obtained. Omitting those in parentheses which differed from the average of the others by more than four times their individual standard deviation, the average value is $69.90 \mathrm{kcal} / \mathrm{mole}$.

\section{b. $5 \mathrm{Mg}(\mathrm{OH})_{2} \cdot \mathrm{MgCl}_{2} \cdot \mathrm{nH}_{2} \mathrm{O}$}

The compound $5 \mathrm{Mg}(\mathrm{OH})_{2} \cdot \mathrm{MgCl}_{2} \cdot n \mathrm{H}_{2} \mathrm{O}$ is metastable at $25^{\circ} \mathrm{C}$ in $\mathrm{MgCl}_{2}$ solutions of all concentrations. It was obtained in the present work as the first precipitate from solutions containing 34 or 36 percent of $\mathrm{MgCl}_{2} \cdot 6 \mathrm{H}_{2} \mathrm{O}$ respectively, and supersaturated with $\mathrm{MgO}$. Most of the samples were obtained by pressing out the solution without washing, but some were obtained by washing the material with alcohol and acetone. The analyses and the heats of solution are given in table 4 . The heats of solution were corrected for the heat of dilution of the $\mathrm{MgCl}_{2}$ solution, or the heats of solution of $\mathrm{Mg}(\mathrm{OH})_{2}$ or $\mathrm{MgCl}_{2} \cdot 6 \mathrm{H}_{2} \mathrm{O}$, as indicated by the analysis and are given in the last column of the table, expressed as kilocalories per mole of the 5:1 compound. The value of $n$ for the 7 samples of washed material varied only over the range 7.798 to 7.955 . Over this short range, correlation was found between the heat of solution and the value of $n$. The heat of solution thus found for $n=8$ was $124.14 \mathrm{kcal} / \mathrm{mole}$ of $5 \mathrm{Mg}(\mathrm{OH})_{2} \cdot \mathrm{MgCl}_{2} \cdot 8 \mathrm{H}_{2} \mathrm{O}$. However, since in some cases differences were found in the X-ray patterns of samples before and after washing, the average value of the heats of solution of both the washed and the pressed samples was taken as the heat of solution in $\mathrm{HCl}, 26.61 \mathrm{H}_{2} \mathrm{O}$ of the $5: 1$ compound. The value found was $125.94 \mathrm{kcal} / \mathrm{mole}$. The standard deviation of the average was 0.30 $\mathrm{kcal} / \mathrm{mole}$. The associated value of $n$ is considered to be 8 in the material as precipitated. Feitknecht and Held [6] found $n$ to be for their preparation after washing and drying, but this value was not approached with the $5: 1$ compound in the present work

\subsection{Heats of Formation}

The heats of formation of the four magnesium oxychlorides were calculated from their heats of solution and the heats of solution of $\mathrm{MgCl}_{2} \cdot 6 \mathrm{H}_{2} \mathrm{O}$ (c) and $\mathrm{Mg}(\mathrm{OH})_{2}$. The samples were small $(0.5$ to $2.0 \mathrm{~g})$ in comparison with the $600 \mathrm{~g}$ of $\mathrm{HCl}, 26.61 \mathrm{H}_{2} \mathrm{O}$ used in the calorimeter. Heats of dilution and differences in final composition of the calorimeter solution from sample to sample were therefore in general neglected. The precision of the measurements did not warrant the labor of determination or calculation of the small corrections generated, for example, by the small deviations in the final concentrations caused by the use of differing small quantities of the various oxychloride preparations. The heats of reaction between $\mathrm{Mg}(\mathrm{OH})_{2}$ (c) (brucite), $\mathrm{MgCl}_{2} \cdot 6 \mathrm{H}_{2} \mathrm{O}$ (c) and $\mathrm{H}_{2} \mathrm{O}$ (1) to form the oxychlorides were calculated from the observed heats of solution and applied with the heats of formation of those reactants [8] to calculate the heats of formation of the oxychlorides. Pertinent data and the calculated results are included in table 5 .

These heats of formation differ from those calculated [8] from the results of Andre's work [7]. He identified the compound obtained from 20.8 percent $\mathrm{MgCl}_{2}$ solution (44.4 percent of $\mathrm{MgCl}_{2} \cdot 6 \mathrm{H}_{2} \mathrm{O}$ ) as $\mathrm{MgO} \cdot \mathrm{MgCl}_{2} \cdot 16 \mathrm{H}_{2} \mathrm{O}$, a compound not reported elsewhere. The proportions given by the average of his

TABLE 4. Heat of solution of $5 \mathrm{Mg}(\mathrm{OH})_{2} \cdot \mathrm{MgCl}_{2} \cdot 8 \mathrm{H}_{2} \mathrm{O}$ preparations in $\mathrm{HCl}, 26.61 \mathrm{H}_{2} \mathrm{O}$

\begin{tabular}{|c|c|c|c|c|c|c|c|}
\hline \multirow{2}{*}{ Sample } & \multicolumn{3}{|c|}{ Composition } & \multicolumn{2}{|c|}{ Molar ratio } & \multirow{2}{*}{$\begin{array}{l}\text { Heat of solu- } \\
\text { tion of } \\
\text { sample }\end{array}$} & \multirow{2}{*}{$\begin{array}{l}\text { Calculated heat of solution } \\
\text { of } 5 \mathrm{Mg}(\mathrm{HO})_{2} \cdot \mathrm{MgCl}_{2} \cdot 8 \mathrm{H}_{2} \mathrm{O}\end{array}$} \\
\hline & $\mathrm{MgO}$ & $\mathrm{MgCl}_{2}$ & $\mathrm{H}_{2} \mathrm{O}$ & $\mathrm{Mg}(\mathrm{OH})_{2} / \mathrm{MgCl}_{2}$ & ${ }^{\mathrm{a}} \mathrm{H}_{2} \mathrm{O} / \mathrm{MgCl}_{2}$ & & \\
\hline $\begin{array}{l}34 \mathrm{P} 1 \mathrm{~b} \\
34 \mathrm{P} 1 \\
34 \mathrm{P} 2 \\
34 \mathrm{P} 3 \\
34 \mathrm{P} 4\end{array}$ & $\begin{array}{c}\% \\
13.88 \\
14.31 \\
10.03 \\
12.95\end{array}$ & $\begin{array}{c}\% \\
17.27 \\
16.91 \\
16.89 \\
16.83\end{array}$ & $\begin{array}{l}\% \\
68.85 \\
68.78 \\
73.08 \\
70.22\end{array}$ & $\begin{array}{l}1.898 \\
1.999 \\
1.403 \\
1.817\end{array}$ & $\begin{array}{l}19.18 \\
21.40 \\
20.24\end{array}$ & $\begin{array}{l}\mathrm{cal} / \mathrm{g} \\
87.9 \\
88.2 \\
89.5 \\
64.0 \\
80.7\end{array}$ & $\begin{array}{c}\text { kcal/mole } \\
127.4 \\
127.9 \\
125.8 \\
128.2 \\
125.4\end{array}$ \\
\hline $\begin{array}{l}\text { 34P5 } \\
\text { 34P6 } \\
34 \mathrm{P7} \\
34 \mathrm{P} 8 \\
36 \mathrm{P} 1\end{array}$ & $\begin{array}{l}17.97 \\
16.98 \\
12.92 \\
13.10 \\
13.88\end{array}$ & $\begin{array}{l}17.58 \\
17.54 \\
16.91 \\
19.38 \\
17.50\end{array}$ & $\begin{array}{l}64.45 \\
65.48 \\
70.17 \\
68.52 \\
68.62\end{array}$ & $\begin{array}{l}\text { 2. } 414 \\
\text { 2. } 287 \\
\text { 1. } 805 \\
\text { 1. } 683 \\
\text { 1. } 873\end{array}$ & $\begin{array}{l}16.96 \\
17.45 \\
20.13 \\
18.02 \\
18.86\end{array}$ & $\begin{array}{r}111.7 \\
104.4 \\
81.7 \\
82.6 \\
88.6\end{array}$ & $\begin{array}{l}125.2 \\
123.7 \\
127.2 \\
126.8 \\
128.4\end{array}$ \\
\hline $\begin{array}{l}36 \mathrm{P} 2 \\
36 \mathrm{P} 3 \\
36 \mathrm{P} 4 \\
36 \mathrm{P} 5 \\
36 \mathrm{~A}\end{array}$ & $\begin{array}{l}12.50 \\
15.62 \\
11.07 \\
14.16 \\
37.85\end{array}$ & $\begin{array}{l}17.67 \\
18.76 \\
17.06 \\
17.73 \\
18.06\end{array}$ & $\begin{array}{l}69.83 \\
65.62 \\
71.87 \\
68.11 \\
44.09\end{array}$ & $\begin{array}{l}\text { 1. } 671 \\
\text { 1. } 967 \\
\text { 1. } 533 \\
\text { 1. } 886 \\
\text { 4. } 950\end{array}$ & $\begin{array}{l}\text { 19. } 22 \\
16.52 \\
20.74 \\
18.42 \\
7.955\end{array}$ & $\begin{array}{r}77.0 \\
97.1 \\
69.2 \\
86.8 \\
234.3\end{array}$ & $\begin{array}{l}123.8 \\
125.0 \\
125.5 \\
123.6 \\
124.8\end{array}$ \\
\hline $\begin{array}{l}36 \mathrm{~A} 2 \\
36 \mathrm{~A} 3 \\
36 \mathrm{~A} 4 \\
36 \mathrm{~A} 5 \\
36 \mathrm{~A} 6 \\
36 \mathrm{~A} 7\end{array}$ & $\begin{array}{l}38.30 \\
39.16 \\
37.95 \\
38.70 \\
38.07 \\
38.33\end{array}$ & $\begin{array}{l}17.93 \\
17.51 \\
18.18 \\
17.78 \\
18.09 \\
17.93\end{array}$ & $\begin{array}{l}43.77 \\
43.33 \\
43.97 \\
43.52 \\
43.84 \\
43.74\end{array}$ & $\begin{array}{l}\text { 5. } 045 \\
\text { 5. } 282 \\
\text { 4. } 931 \\
\text { 5. } 141 \\
\text { 4. } 971 \\
\text { 5. } 049\end{array}$ & $\begin{array}{l}7.859 \\
7.799 \\
7.825 \\
7.798 \\
7.839 \\
7.846\end{array}$ & $\begin{array}{l}238.4 \\
247.0 \\
237.4 \\
242.6 \\
238.0 \\
239.0\end{array}$ & $\begin{array}{l}125.4 \\
126.8 \\
126.1 \\
126.2 \\
125.9 \\
125.6\end{array}$ \\
\hline
\end{tabular}

a Corrected for water equivalent to $\mathrm{MgO}$ to form $\mathrm{Mg}(\mathrm{OH})_{2}$.

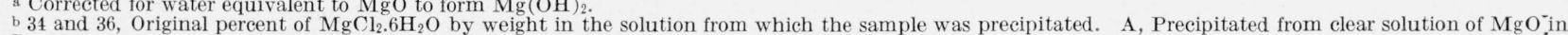

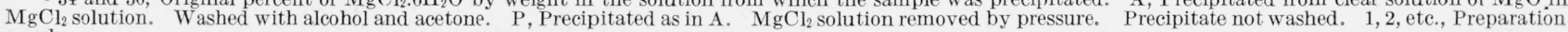
number. 
TABLE 5. Heats of solution and formation of magnesium oxychlorides

\begin{tabular}{|c|c|c|}
\hline \multirow[b]{2}{*}{ Compound } & \multicolumn{2}{|c|}{$\Delta \mathrm{H}_{298}$} \\
\hline & $\begin{array}{c}\text { Heat of } \\
\text { solution in } \\
\mathrm{HCl} 26.61 \mathrm{H}_{2} \mathrm{O}\end{array}$ & $\begin{array}{l}\text { Heat of } \\
\text { formation }\end{array}$ \\
\hline 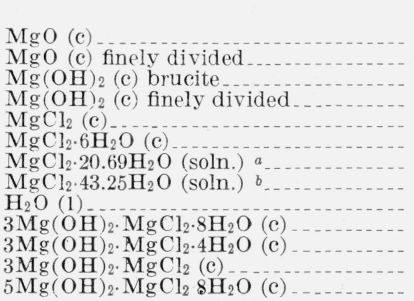 & $\begin{array}{c}k c a l / \text { mole } \\
-25.64[12] \\
-26.88[12] \\
-1.65 \\
-0.42 \\
-0.017[16] \\
-69.61 \\
-81.43 \\
-103.96 \\
-125.94\end{array}$ & $\begin{array}{c}\text { kcal mole } \\
-143.84[8 \\
-142.95[8 \\
-221.00[8 \\
-153.40[8] \\
-597.42[8] \\
-188.12[8] \\
-189.03[8] \\
-68.317[8] \\
-1409.05 \\
-1123.90 \\
-828.04 \\
-1848.00\end{array}$ \\
\hline
\end{tabular}

- $22^{\circ}$ B solution

$b$ Solution containing 10.69 percent of $\mathrm{MgCl}_{2}$.

analyses are $0.94: 1.00: 15.8$. Since his material was dried on paper it contained magnesium chloride solution in unknown amount, and because of his method of preparing the supersaturated solution of $\mathrm{MgO}$ in $\mathrm{MgCl}_{2}$, of unknown concentration. Andre's description of his method of preparation is incomplete, because he did not give times of heating, but attempts were made to duplicate his procedure. When successful, these resulted in products which the X-ray patterns indicated were mixtures of the 5:1 and the 3:1 oxychlorides. The proportions varied with the time of standing before filtration, the 5:1 oxychloride predominating at short times. The heats of solution of these preparations were not determined.

\subsection{Heat of Hardening of Magnesium Oxychloride Cement}

The potential heat of hardening of magnesium oxychloride cement can be calculated from the heats of formation of the oxychlorides. As Rodt [17] and others have pointed out, the reaction of $\mathrm{MgO}$ and $\mathrm{MgCl}_{2}$ solution is incomplete in a paste of a usable consistency because insufficient $\mathrm{MgCl}_{2}$ solution is present. If the assumption is made that the concentration of the $\mathrm{MgCl}_{2}$ solution does not fall below that given by Bury and Davies [4] as necessary to maintain the stability of the $3: 1$ oxychloride, 10.89 percent, the extent of the reaction can be calculated. Such a calculation was made for a paste made of 40 percent of $\mathrm{MgO}$ and 60 percent of $22^{\circ} \mathrm{B} \mathrm{MgCl}_{2}$ solution, a composition approximating those used in actual practice. The X-ray pattern of such a paste showed that at 254 days it consisted of the 5:1 oxychloride and $\mathrm{Mg}(\mathrm{OH})_{2}$. The observed heat of hardening [18] was $235 \mathrm{cal} / \mathrm{g} \mathrm{MgO}$ at 60 days. The potential heat of hardening calculated, based on the formation of $\mathrm{Mg}(\mathrm{OH})_{2}$, the $5: 1$ oxychloride, and 10.89 percent $\mathrm{MgCl}_{2}$ solution, was $265 \mathrm{cal} / \mathrm{g}$ of $\mathrm{MgO}$. Only about one half of the $\mathrm{MgO}$ would be converted to the $5: 1$ compound under the conditions assumed, the rest would be present as $\mathrm{Mg}(\mathrm{OH})_{2}$. Details of the calculation are shown in the appendix. As indicated there, by far the greater part of the heat evolved is due to the hydration of the magnesia to magnesium hydroxide.

The author gratefully acknowledges the assistance of Leonard P. Suffredini who prepared many of the samples of $5 \mathrm{Mg}(\mathrm{OH})_{2} \cdot \mathrm{MgCl}_{2} \cdot 8 \mathrm{H}_{2} \mathrm{O}$ and determined their heats of solution.

\section{References}

[1] W. O. Robinson and W. A. Waggaman, J. Phys. Chem. 13, 673 (1909).

[2] H. S. Lukens, J. Am. Chem. Soc. 54, 2372 (1932).

[3] L. Chassevent, Chimie \& industrie 30, 1020 (1933).

[4] C. R. Bury and E. R. H. Davies, J. Chem. Soc. (London) (a) 1932, 2008; (b) 1933, 701 .

[5] W. Feitknecht, Helv. Chim. Acta 9, 1018 (1926); 10, $140(1927) ; 13,1380(1930)$.

[6] W. Feitknecht and F. Held, Helv. Chim. Acta 2\%, 1480 (1944).

[7] G. Andre, Ann. chim. et phys. [6] 3, 79 (1884).

[8] Selected Values of Chemical Thermodynamic Properties, Cir. NBS 500 (1952) (U. S. Government Printing Office Washington 25, D. C.).

[9] International Critical Tables, National Research Council (McGraw-Hill Book Co., Inc., New York, N. Y.).

[10] E. S. Newman and L. S. Wells, J. Research NBS 20, 825 (1938) RP1107.

[11] W. P. White, The Modern Calorimeter (The Chemical Catalog Co., New York, N. Y., 1928).

[12] K. Taylor and L. S. Wells, J. Research NBS 21, 133 (1938) RP1121.

[13] Handbook of Chemistry and Physics (Chemical Rubber Publishing Co., Cleveland, Ohio, 1939).

[14] G. Wehner, Z. anorg. u. allgem. Chem. 272, 201 (1953).

[15] E. T. Carlson, R. B. Peppler, and L. S. Wells, J. Research NBS 51, 179 (1953) RP2448.

[16] F. D. Rossini, BS J. Research 9, 679 (1932) RP499.

[17] V. Rodt, Zement $\mathbf{2 6}, 597$ (1937).

[18] E. S. Newman, J. V. Gilfrich, and L. S. Wells, J. Research NBS 49, 377 (1952) RP2375.

[19] E. S. Newman and L. S. Wells, J. Research NBS 36, 137 (1946) RP1696.

[20] F. R. Bichowsky and F. D. Rossini, The Thermochemistry of the Chemical Substances (Reinhold Publishing Corp., New York, N. Y., 1936).

\section{Appendix}

Calculation of the composition and potential heat of hardening of a paste consisting of $40 \mathrm{~g} \mathrm{MgO}$ and $60 \mathrm{~g}$ of $22^{\circ} \mathrm{B} \mathrm{MgCl}$ solution $\left(\mathrm{MgCl}_{2}, 20.69 \mathrm{H}_{2} \mathrm{O}\right)$.

Products: $5 \mathrm{Mg}(\mathrm{OH})_{2} \cdot \mathrm{MgCl}_{2} \cdot 8 \mathrm{H}_{2} \mathrm{O}, \quad \mathrm{Mg}(\mathrm{OH})_{2}$, and 10.89 percent $\mathrm{MgCl}_{2}$ solution $\left(\mathrm{MgCl}_{2}, 43.254 \mathrm{H}_{2} \mathrm{O}\right)$.

Basis: $100 \mathrm{~g}$ of paste

$0.9921 \mathrm{MgO}+0.1282\left(\mathrm{MgCl}_{2}, 20.69 \mathrm{H}_{2} \mathrm{O}\right)$

$=\mathrm{X} \mathrm{Mg}(\mathrm{OH})_{2}+\mathrm{Y}\left(5 \mathrm{Mg}(\mathrm{OH})_{2} \cdot \mathrm{MgCl}_{2} \cdot 8 \mathrm{H}_{2} \mathrm{O}\right)+$

$\mathrm{Z}\left(\mathrm{MgCl}_{2}, 43.254 \mathrm{H}_{2} \mathrm{O}\right)$

$\mathrm{MgO}=0.9921=\mathrm{X}+5 \mathrm{Y}$,

$\mathrm{MgCl}_{2}=0.1282=\mathrm{Y}+\mathrm{Z}$,

$\mathrm{H}_{2} \mathrm{O}=2.65246=\mathrm{X}+13 \mathrm{Y}+43.254 \mathrm{Z}$.

Solving; $\mathrm{X}=0.4411, \mathrm{Y}=0.1102, \mathrm{Z}=0.01801$

Therefore the desired equation is:

$0.9921 \mathrm{MgO}(\mathrm{c})+0.1282\left(\mathrm{MgCl}_{2}, 20.69 \mathrm{H}_{2} \mathrm{O}\right)$ (soln.)

$=0.4411 \mathrm{Mg}(\mathrm{OH})_{2}(\mathrm{c})+0.1102$

$\left(5 \mathrm{Mg}(\mathrm{OH})_{2} \cdot \mathrm{MgCl}_{2} \cdot 8 \mathrm{H}_{2} \mathrm{O}\right)(\mathrm{c})$

$+0.01801\left(\mathrm{MgCl}_{2}, 43.254 \mathrm{H}_{2} \mathrm{O}\right)($ soln. $)+\Delta \mathrm{H}$. 
This equation is the sum of the following equations: $0.9921 \mathrm{MgO}(\mathrm{c}$, finely divided $)+0.9921 \mathrm{H}_{2} \mathrm{O}(1)$ $=0.9921 \mathrm{Mg}(\mathrm{OH})_{2}(\mathrm{c}), \Delta \mathrm{H}_{1}=-9.656 \mathrm{kcal}$

$0.5510 \mathrm{Mg}(\mathrm{OH})_{2}(\mathrm{c})+0.1102\left(\mathrm{MgCl}_{2} \cdot 6 \mathrm{H}_{2} \mathrm{O}\right)(\mathrm{c})+$ $0.2204 \mathrm{H}_{2} \mathrm{O}(\mathrm{l})=0.1102\left(5 \mathrm{Mg}(\mathrm{OH})_{2} \cdot \mathrm{MgCl}_{2} \cdot 8 \mathrm{H}_{2} \mathrm{O}\right)(\mathrm{c})$, $\Delta \mathrm{H}_{2}=-0.986 \mathrm{kcal}$

$0.1102 \mathrm{MgCl}_{2}(\mathrm{c})+0.6612 \mathrm{H}_{2} \mathrm{O}(\mathrm{l})=0.1102\left(\mathrm{MgCl}_{2} \cdot 6 \mathrm{H}_{2} \mathrm{O}\right.$. (c), $\left.\Delta \mathrm{H}_{3}=-3.760 \mathrm{kca}\right]$

$0.1102\left(\mathrm{MgCl}_{2} \cdot 20.69 \mathrm{H}_{2} \mathrm{O}\right)$ (soln.)

$=0.1102 \mathrm{MgCl}_{2}(\mathrm{c})+2.2800 \mathrm{H}_{2} \mathrm{O}(\mathrm{l}), \Delta \mathrm{H}_{4}=$ +3.826 kcal.
$0.01801\left(\mathrm{MgCl}_{2} \cdot 20.69 \mathrm{H}_{2} \mathrm{O}\right)$ (soln.)

$+0.4063 \mathrm{H}_{2} \mathrm{O}=01801\left(\mathrm{MgCl}_{2} \cdot 43.25 \mathrm{H}_{2} \mathrm{O}\right)$ (soln.), $\Delta \mathrm{H}_{5}=-0.016 \mathrm{kcal}$.

The $\Delta \mathrm{H}$ of eq (A) is the sum of the five $\Delta H$ 's shown. These have been calculated in the usual manner [20] from the data in table 5 .

The $\Delta \mathrm{H}$ of eq $(\mathrm{A})$ is found to be $-10.59 \mathrm{kcal}$ or $265 \mathrm{cal} / \mathrm{g} \mathrm{MgO}$.

Washington, November 5, 1954. 